\title{
Faktor-Faktor yang Mempengaruhi Struktur Modal pada Perusahaan Industri Barang Konsumsi
}

\author{
Rika Rizky Ayuningtyas ${ }^{1}$, Suhendro ${ }^{2}$, Purnama Siddi ${ }^{3}$ \\ ${ }^{1,2,3}$ Universitas Islam Batik, JL. KH Agus Salim No. 10, Surakarta, Indonesia \\ Correspondence email: rikarizky382@gmail.com
}

\begin{abstract}
Abstrak. Penelitian ini bertujuan untuk mengetahui faktor-faktor yang berpengaruh terhadap struktur modal. Variabel independen dalam penelitian ini adalah struktur aktiva, ukuran perusahaan, likuiditas dan profitabilitas. Populasi penelitian ini adalah 43 perusahaan industri barang konsumsi yang terdaftar di BEI periode 2016-2018. Dengan menggunakan teknik purposive sampling, sebanyak 62 perusahaan yang memenuhi kriteria sampel. Metode yang digunakan regresi linier berganda. Hasil penelitian ini menunjukkan bahwa secara simultan variabel struktur aktiva, ukuran perusahaan, likuiditas, dan profitabilitas berpengaruh terhadap struktur modal. Hasil penelitian secara parsial variabel likuiditas berpengaruh terhadap struktur modal. Sedangkan, pada variabel struktur aktiva, ukuran perusahaan, dan profitabilitas tidak berpengaruh terhadap struktur modal.
\end{abstract}

Kata kunci: struktur aktiva; ukuran perusahaan; likuiditas; profitabilitas; struktur modal

\begin{abstract}
This study aims to determine the factors that influence capital structure. The independent variables in this study are asset structure, company size, liquidity and profitability. The population of this research is 43 consumer goods industry companies listed on the Indonesia Stock Exchange for the period of 2016-2018. By using purposive sampling technique, as many as 62 companies met the sample criteria. The method used is multiple linear regression. The results of this study indicate that simultaneously asset structure, company size, liquidity, and profitability variables affect the capital structure. The research results partially liquidity variables affect the capital structure. Meanwhile, the variable asset structure, company size, and profitability does not affect the capital structure.
\end{abstract}

Keywords: asset structure, size, liquidity, profitability, capital structure

\section{PENDAHULUAN}

Persaingan dunia bisnis yang sudah semakin ketat dewasa ini membuat perusahaan berupaya untuk meningkatkan nilai perusahaan. Perusahaan yang beroperasi tidak hanya berorientasi pada pencapaian laba maksimal, namun juga meningkatkan kemakmuran pemilik agar bisnis dapat berjalan dengan lancar. Perusahaan harus memiliki rencana yang taktis dan strategis agar pencapaian tujuan tersebut dapat diterapkan dalam perusahaan. Menurut Batubara et all (2017), menyatakan bahwa banyak perusahaan melakukan berbagai cara untuk mengembangkan usahanya, dan tentulah tidak sedikit dana yang dibutuhkan perusahaan untuk mengembangkan serta menjalankan kegiatan usaha perusahaan.

Modal merupakan salah satu instrumen yang penting dalam mengembangkan keberlangsungan operasional suatu perusahaan, terutama perusahaan yang bergerak dalam sektor industri barang konsumsi. Struktur modal adalah perimbangan atau perbandingan antara modal asing dengan modal sendiri. Pendanaan jangka panjang perusahaan yang ditunjukkan struktur modal berupa hutang, ekuitas, saham preferen atau saham biasa. Sedangkan, modal sendiri terbagi atas laba ditahan dan penyertaan kepemilikan perusahaan. Tingkat resiko suatu perusahaan dapat ditunjukkan dengan semakin tinggi rasio struktur modal nya, maka perusahaan semakin tinggi pula resikonya, dengan kata lain pendanaan dari unsur hutang lebih besar daripada modal sendiri. Menurut Brigham \& Houston (2006), menyatakan bahwa penggunaan utang yang semakin tinggi menyebabkan kenaikan risiko perusahaan, kemudian kenaikan risiko yang tinggi akan menyebabkan pihak debt holder/kreditur juga menetapkan suku bunga yang tinggi pada pinjamannya kepada perusahaan.

Menurut penelitian Denziana \& Yunggo (2017), yang menyimpulkan bahwa struktur aktiva berpengaruh positif dan signifikan terhadap struktur modal, ukuran perusahaan berpengaruh positif dan signifikan terhadap struktur modal, dan profitabilitas berpengaruh negatif dan signifikan terhadap struktur modal. Lasut et all (2018), menyatakan bahwa likuiditas berpengaruh negatif dan signifikan terhadap struktur modal perusahaan.

Berdasarkan hasil penelitian terdahulu, maka memunculkan perumusan masalah dalam penelitian berikut: "Bagaimana pengaruh struktur aktiva, ukuran perusahaan, likuiditas, dan profitabilitas terhadap struktur modal pada perusahaan industri barang konsumsi periode 2016-2018?". Tujuan penelitian ini adalah untuk mengetahui pengaruh struktur aktiva, ukuran perusahaan, likuiditas, dan profitabilitas terhadap struktur modal pada perusahaan industri barang konsumsi periode 2016-2018. Manfaat dari penelitian ini adalah Penelitian ini diharapkan mampu menjadi 
referensi bagi peneliti selanjutnya untuk mengembangkan ataupun membuat penelitian baru di bidang laporan keuangan khususnya di sektor industri barang konsumsi.

\section{METODE}

Jenis penelitian yang digunakan dalam penelitian ini adalah penelitian kuantitatif. Menurut Ariani \& Wiagustini (2017) penelitian yang analisisnya ditekankan pada data angka yang diperoleh dengan metode statistik serta dilakukan dalam rangka pengujian hipotesis sehingga diperoleh signifikansi hubungan antara variabel yang diteliti. Variabel dependen dalam penelitian ini adalah struktur modal. Dalam penelitian ini struktur modal dihitung dengan menggunakan debt equity ratio (DER). DER merupakan variabel yang mendefinisikan seberapa banyak proporsi dari modal perusahaan yang sumber pendanaannya berasal dari pinjaman atau kredit (Horne \& John M, 2012). Rumusnya adalah sebagai berikut:

\section{DER = $\quad$ Total Utang \\ Total Ekuitas}

Variabel independen dalam penelitian ini adalah:

\section{Struktur Aktiva}

Struktur aktiva adalah segala sumber daya atau harta yang dimiliki perusahaan untuk digunakan dalam operasinya. Struktur aktiva merupakan komposisi aktiva yang dimiliki perusahaan. Rasio fixed assets adalah perbandingan jumlah aktiva tetap dengan keseluruhan aktiva. Rasio ini digunakan sebagai proksi atas variabel struktur aset yang menggambarkan kemampuan perusahaan memperoleh hutang didasarkan dengan besarnya aktiva tetap perusahaan yang dapat dijadikan jaminan (Dewiningrat \& Mustanda, 2018). Rumusnya adalah sebagai berikut:

\section{Struktur Aktiva = Aktiva Tetap Total Aktiva}

\section{Ukuran Perusahaan}

Ukuran perusahaan dalam penelitian ini merupakan cerminan dari besar kecilnya nilai total aktiva perusahaan pada akhir tahun, yang diukur menggunakan lognatural (Ln) dari total aktiva (Brigham \& Houston, 2006). Rumusnya adalah sebagai berikut :

\section{Ukuran Perusahaan $=\operatorname{Ln} T A$}

\section{Likuiditas}

Rasio likuiditas adalah perbandingan yang menunjukkan kemampuan suatu perusahaan untuk segera menyelesaikan kewajiban jangka pendek yang segera jatuh tempo. Rasio lancar digunakan untuk menunjukkan tingkat keamanan (margin of safety) kreditor jangka pendek, atau merupakan tingkat kemampuan perusahaan dalam memenuhi kewajiban jangka pendeknya, dengan kata lain, seberapa banyak aktiva lancar yang tersedia untuk menutupi kewajiban jangka pendek yang segera jatuh tempo (Dahlena, 2017). Rumusnya adalah sebagai berikut:

\section{Current Ratio $=\quad \underline{\text { Aktiva Lancar }}$ Hutang Lancar}

\section{Profitabilitas}

Profitabilitas adalah kemampuan perusahaan untuk menghasilkan laba pada periode tertentu. Profitabilitas dalam penelitian ini menggunakan pengukuran return on assets (ROA). Return on assets (ROA) adalah rasio yang digunakan untuk mengukur efektivitas perusahaan dalam menghasilkan keuntungan dengan memanfaatkan aktiva yang dimiliki. Menurut (Horne \& John M, 2012). Nilai ROA dapat dihitung dengan rumus:

\section{ROA $=\quad$ Laba Bersih Setelah Pajak Total Aktiva}

\section{HASIL DAN PEMBAHASAN}

Tabel 1. Hasil Uji Normalitas

\begin{tabular}{ccc}
\hline Variabel & $\begin{array}{c}\text { Kolmogorov- } \\
\text { Smirnov }\end{array}$ & Standard \\
\hline $\begin{array}{c}\text { Struktur aktiva } \\
\text { Ukuran perusahaan } \\
\text { Likuitas } \\
\text { Profitabilitas }\end{array}$ & 0,200 & $>0,05$ \\
\hline
\end{tabular}

Berdasarkan hasil uji normalitas dalam penelitian ini menunjukkan nilai signifikansi sebesar 0,200 > 0,05, maka penelitian ini dapat disimpulkan bahwa data berdistribusi normal.

Tabel 2. Hasil Uji Multikolinearitas

\begin{tabular}{|c|c|c|c|c|c|}
\hline Variabel & $\begin{array}{c}\text { Tolera } \\
\text { nce }\end{array}$ & Std. & VIF & Std. & Keterangan \\
\hline $\begin{array}{c}\text { Struktur } \\
\text { aktiva }\end{array}$ & 0,667 & $>0,1$ & 1,500 & $<10$ & $\begin{array}{c}\text { Tidak terjadi } \\
\text { multikolinieritas }\end{array}$ \\
\hline $\begin{array}{c}\text { Ukuran } \\
\text { perusahaan }\end{array}$ & 0,770 & $>0,1$ & 1,299 & $<10$ & $\begin{array}{c}\text { Tidak terjadi } \\
\text { multikolinieritas }\end{array}$ \\
\hline Likuiditas & 0,841 & $>0,1$ & 1,189 & $<10$ & $\begin{array}{c}\text { Tidak terjadi } \\
\text { multikolinieritas }\end{array}$ \\
\hline Profitabilitas & 0,665 & $>0,1$ & 1,503 & $<10$ & $\begin{array}{c}\text { Tidak terjadi } \\
\text { multikolinieritas }\end{array}$ \\
\hline
\end{tabular}

Berdasarkan hasil uji multikolinieritas yang didapat dari penelitian ini bahwa nilai variabel independen memiliki nilai tolerance $>0,1$ dan nilai VIF $<10$, sehingga dapat disimpulkan bahwa penelitian ini tidak terjadi multikolinieritas. 
Tabel 3. Hasil Uji Autokorelasi

\begin{tabular}{cccc}
\hline Model & $\begin{array}{c}\text { Durbin- } \\
\text { Watson }\end{array}$ & $\begin{array}{c}\text { Syarat Durbin- } \\
\text { Watson }\end{array}$ & Hasil \\
\hline 1 & 2,228 & DU $<$ DW < 4-DU & $\begin{array}{c}\text { Tidak terjadi } \\
\text { Autokorelasi }\end{array}$ \\
\hline
\end{tabular}

Berdasarkan hasil uji autokorelasi diatas diperoleh nilai Durbin-Watson sebesar 2,228. Untuk jumlah sampel sebanyak 62 dan $\mathrm{k}=4$ diperoleh nilai $\mathrm{DL}=$ 1,4554 dan $\mathrm{DU}=1,7288$. Jadi nilai $4-\mathrm{DU}=2,2712$ sehingga $\mathrm{DU}<\mathrm{DW}<4-\mathrm{DU}=1,7288<2,228<2,2712$. Dapat disimpulkan bahwa tidak terjadi autokorelasi (bebas autokorelasi).

Tabel 4. Hasil Uji Heteroskedastisitas

\begin{tabular}{cccc}
\hline Variabel & $\begin{array}{c}\text { Unstand } \\
\text { ardized } \\
\text { Residual }\end{array}$ & Std. & Keterangan \\
\hline H1 & 0,793 & $>0,05$ & Bebas Heteroskedastisitas \\
H2 & 0,617 & $>0,05$ & Bebas Heteroskedastisitas \\
H3 & 0,705 & $>0,05$ & Bebas Heteroskedastisitas \\
H4 & 0,890 & $>0,05$ & Bebas Heteroskedastisitas \\
\hline
\end{tabular}

Berdasarkan hasil uji heteroskedastisitas diatas dapat dilihat bahwa korelasi antar semua variabel independen dengan Unstandardized Residual memiliki nilai signifikansi > 0,05, maka dapat disimpulkan bahwa tidak terjadi masalah heteroskedastisitas.

Tabel 5. Hasil Uji Regresi

\begin{tabular}{cc}
\hline Variabel & B \\
\hline (Konstant) & 0,788 \\
Struktur aktiva & 0,161 \\
Ukuran Perusahaan & 0,009 \\
Likuiditas & $-0,182$ \\
Profitabilitas & 0,142 \\
\hline
\end{tabular}

$Y=0,788+0,161 X 1+0,009 X 2-0,182 X 3+0,142$ $\mathrm{X} 4$

Untuk menginterprestasikan hasil dari analisis tersebut dapat diterangkan sebagai berikut:

1) Nilai Konstanta Variabel Struktur Modal $(\mathrm{Y})=0,788$ Uji model regresi memiliki nilai konstanta sebesar 0,788 secara sistematis menyatakan bahwa jika nilai variabel bebas $\mathrm{X} 1, \mathrm{X} 2, \mathrm{X} 3$ dan $\mathrm{X} 4$ sama dengan nol (0), maka nilai Y adalah 0,788.

2) Koefisien Regresi Variabel Struktur Aktiva (X1) = 0,161

Hal ini berarti apabila struktur aktiva mengalami kenaikan 1 satuan, maka struktur modal akan diikuti kenaikan sebesar 0,161 dengan asumsi nilai koefisien variabel independen lainnya dianggap tetap atau sama dengan nol.

3) Koefisien Regresi Variabel Ukuran Perusahaan (X2) $=0,009$

Hal ini berarti apabila ukuran perusahaan mengalami kenaikan 1 satuan, maka struktur modal akan diikuti kenaikan sebesar 0,009 dengan asumsi nilai koefisien variabel independen lainnya dianggap tetap atau sama dengan nol.

4) Koefisien Regresi Variabel Likuiditas (X3) $=-0,182$ Hal ini berarti apabila struktur aktiva mengalami kenaikan 1 satuan, maka struktur modal akan mengalami penurunan sebesar -0,182 dengan asumsi nilai koefisien variabel independen lainnya dianggap tetap atau sama dengan nol.

5) Koefisien Regresi Variabel Profitabilitas (X4) = 0,142

Hal ini berarti apabila struktur aktiva mengalami kenaikan 1 satuan, maka struktur modal akan diikuti kenaikan sebesar 0,142 dengan asumsi nilai koefisien variabel independen lainnya dianggap tetap atau sama dengan nol.

Table 6. Hasil Uji Kelayakan Model (Uji F)

\begin{tabular}{cccccc}
\hline Ket. & F $_{\text {hitung }}$ & $\mathbf{F}_{\text {tabel }}$ & Sig & Kriteria & Hasil \\
\hline $\begin{array}{c}\text { Uji } \\
\text { Kelayak }\end{array}$ & & & & & \\
an & 20,94 & 2,534 & 0,000 & $<0,05$ & $\begin{array}{c}\text { Model } \\
\text { Model }\end{array}$ \\
$\begin{array}{c}\text { (Uji F) } \\
\text { (Uayak }\end{array}$ & & & & & \\
\hline
\end{tabular}

Berdasarkan table diatas diketahui bahwa nilai sig yang di dapatkan pada uji $\mathrm{F}$ adalah $0,000<0,05$, maka dapat disimpulkan bahwa model memenuhi kelayakan.

Tabel 7. Hasil Uji Hipotesis (Uji t)

\begin{tabular}{|c|c|c|c|c|c|}
\hline Hipotesis & $\begin{array}{c}\text { T- } \\
\text { hitung }\end{array}$ & T-tabel & Sig & Std. & $\begin{array}{c}\text { Ketera } \\
\text { ngan }\end{array}$ \\
\hline H1 & 0,740 & $<2,002$ & 0,462 & $>0,05$ & $\begin{array}{c}\mathrm{H} 1 \\
\text { ditolak }\end{array}$ \\
\hline $\mathrm{H} 2$ & 1,623 & $<2,002$ & 0,110 & $>0,05$ & $\begin{array}{c}\mathrm{H} 2 \\
\text { ditolak } \\
\mathrm{H} 3\end{array}$ \\
\hline H3 & $-8,313$ & $<-2,002$ & 0,000 & $<0,05$ & $\begin{array}{c}\text { diterim } \\
\mathrm{a}\end{array}$ \\
\hline $\mathrm{H} 4$ & 0,188 & $<2,002$ & 0,852 & $>0,05$ & $\begin{array}{c}\mathrm{H} 4 \\
\text { ditolak } \\
\end{array}$ \\
\hline
\end{tabular}

Berdasarkan hasil output di atas, dapat disimpulkan bahwa :

1. Nilai t-hitung variabel struktur aktiva sebesar $0,740<$ 2,002 , dan nilai sig sebesar $0,462>0,05$, yang menunjukkan bahwa variabel struktur aktiva secara parsial tidak berpengaruh terhadap struktur modal.

2. Nilai t-hitung variabel ukuran perusahaan sebesar $1,623<2,002$, dan nilai sig sebesar $0,110>0,05$, yang menunjukkan bahwa variabel ukuran perusahaan secara parsial tidak berpengaruh terhadap struktur modal.

3. Nilai t-hitung variabel likuiditas sebesar $-8,313<-$ 2,002, dan nilai sig sebesar $0,000<0,05$, yang menunjukkan bahwa variabel likuiditas secara parsial berpengaruh terhadap struktur modal.

4. Nilai t-hitung variabel profitabilitas sebesar $0,188<$ 2,002 , dan nilai sig sebesar $0,852>0,05$, yang 
menunjukkan bahwa variabel profitabilitas secara parsial tidak berpengaruh terhadap struktur modal.

Tabel 8. Hasil Uji Koefisien Determinasi

\begin{tabular}{ccc}
\hline Model & $\begin{array}{c}\text { Adjusted } \\
\text { R Square }\end{array}$ & Keterangan \\
\hline $\mathbf{1}$ & 0,567 & $\begin{array}{c}\text { Variabel dependen dapat dijelaskan } \\
\text { oleh variabel independen }\end{array}$ \\
\hline
\end{tabular}

Berdasarkan hasil uji koefisien determinasi pada penelitian ini diperoleh nilai sebesar 0,567. Menunjukkan bahwa struktur modal dipengaruhi oleh struktur aktiva, ukuran perusahaan, likuiditas dan profitabilitas sebesar $56,7 \%$ sedangkan sisanya $43,3 \%$ dipengaruhi oleh faktor yang lain yang tidak diteliti dalam penelitianini.

\section{Pembahasan}

\section{Pengaruh Struktur Aktiva Terhadap Struktur Modal}

Hasil hipotesis 1 menunjukkan bahwa struktur aktiva tidak berpengaruh terhadap struktur modal pada perusahaan industri barang konsumsi yang terdaftar di BEI periode 2016-2018. Tidak berpengaruhnya struktur aktiva terhadap struktur modal dikarenakan tidak sesuai dengan rumusan hipotesis, dimana semakin besar aktiva tetap yang dimiliki perusahaan maka perusahaan dapat menggunakan utang dalam jumlah yang besar pula. Hal ini disebabkan sebagian perusahaan yang menggunakan modal yang tertanam dari aktiva tetap cenderung lebih mengutamakan modalnya sendiri. Hasil ini sejalan dengan penelitian Maryanti (2016), yang menunjukkan bahwa struktur aktiva tidak berpengaruh terhadap struktur modal, karena tidak semua perusahaan menggunakan aktiva untuk jaminan hutang. Namun, penelitian ini tidak sejalan dengan Apsari \& Dana (2018), yang menunjukkan bahwa struktur aktiva berpengaruh terhadap struktur modal.

\section{Pengaruh Ukuran Perusahaan Terhadap Struktur Modal}

Hasil hipotesis 2 menunjukkan bahwa ukuran perusahaan tidak berpengaruh terhadap struktur modal pada perusahaan industri barang konsumsi yang terdaftar di BEI periode 2016-2018. Hal ini ditunjukkan dengan besar kecilnya suatu perusahaan tidak mempengaruhi pendanaan terhadap struktur modal, karena dalam penggunaan sumber dana yang berasal dari modal sendiri atau hutang, tentu mempunyai biaya modal yang berbeda dengan tingkat resiko yang berbeda pula. Dalam setiap perusahaan tentu lebih memilih untuk menggunakan pendanaan secara internal sesuai dengan teory pecking order. Hal ini sejalan dengan penelitian Tangiduk et all (2017), yang menunjukkan bahwa tidak berpengaruhnya ukuran perusahaan terhadap struktur modal dikarenakan oleh banyaknya pengukuran yang digunakan sebagai indikator ukuran perusahaan. Hasil ini tidak sejalan dengan penelitian yang dilakukan oleh Apsari \& Dana (2018), yang menunjukkan bahwa ukuran perusahaan berpengaruh terhadap struktur modal, karena besar kecilnya suatu perusahaan ternyata tidak mempengaruhi pendanaan terhadap struktur modalnya.

\section{Pengaruh Likuiditas Terhadap Struktur Modal}

Hasil hipotesis 3 menunjukkan bahwa likuiditas berpengaruh terhadap struktur modal pada perusahaan industri barang konsumsi yang terdaftar di BEI periode 2016-2018. Likuiditas merupakan kemampuan perusahaan untuk memenuhi kewajiban jangka pendeknya, hal ini dapat ditunjukkan bahwa likuiditas suatu perusahaan yang semakin tinggi maka akan semakin kecil pula penggunaan hutang yang digunakan perusahaan tersebut. Berdasarkan dengan teory pecking order dimana kondisi likuiditas perusahaan yang tinggi, maka perusahaan akan cenderung memilih menggunakan pendanaan internal untuk pembiayaan operasional perusahaan dibandingkan dengan penggunaan modal asing atau hutang. Hal ini sejalan dengan penelitian Dewiningrat \& Mustanda (2018), yang menunjukkan bahwa perusahaan dengan kondisi likuditas yang tinggi cenderung menggunakan pendanaan internal dalam hal pembiayaan dan operasional perusahaan. Namun, penelitian ini tidak sejalan dengan penelitian (Firmanullah \& Darsono (2017), yang menunjukkan bahwa likuiditas tidak berpengaruh terhadap struktur modal.

\section{Pengaruh Profitabilitas Terhadap Struktur Modal}

Hasil hipotesis 4 menunjukkan bahwa profitabilitas tidak berpengaruh terhadap struktur modal pada perusahaan industri barang konsumsi yang terdaftar di BEI periode 2016-2018. Hal ini bisa disebabkan dengan adanya kemungkinan tingkat profitabilitas perusahaan yang rendah, maka perusahaan akan cenderung menggunakan penggunaan utang yang lebih banyak untuk membiayai kegiatan operasional perusahaan. Dimana perusahaan akan kesulitan saat tidak mampu menutup beban hutang yang dimiliki oleh perusahaan pada masa lampau. Hal ini tidak bisa disesuaikan dengan teori pecking order yang menyatakan bahwa semakin tinggi tingkat profitabilitas perusahaan, maka akan semakin tinggi pula penggunaan dana internal, dan memerlukan hutang yang lebih sedikit. Hal ini sejalan dengan penelitian Firmanullah \& Darsono (2017), yang menunjukkan bahwa kedua variabel memiliki hubungan negatif, dimana jika profitabilitas semakin tinggi maka struktur modal semakin rendah. Sesuai dengan pecking order theory, jika perusahaan mempunyai dana internal yang tinggi maka perusahaan akan memprioritaskan penggunaan dana dari dalam perusahaan terlebih dahulu sebelum menggunakan dana dari luar perusahaan. Namun, penelitian ini tidak sejalan dengan (Dahlena, 2017). 


\section{SIMPULAN}

Penelitian ini bertujuan untuk mengetahui pengaruh dari struktur aktiva, ukuran perusahaan, likuiditas dan profitabilitas terhadap struktur modal pada perusahaan industri barang konsumsi yang terdaftar di BEI periode 2016-2018. Proses pengambilan sampel pada penelitian ini menggunakan metode purposive sampling yang hasil akhirnya diperoleh sebanyak 62 observasi yang memenuhi kriteria. Berdasarkan Hasil penelitian ini mengindikasi bahwa :

1. Struktur aktiva dalam penelitian ini tidak berpengaruh terhadap struktur modal. Hal ini terjadi karena tidak sesuai dengan rumusan hipotesis, dimana semakin tinggi struktur aktiva maka utangnya juga semakin tinggi. Hal ini disebabkan sebagian perusahaan yang menggunakan modal yang tertanam dari aktiva tetap cenderung lebih mengutamakan modalnya sendiri. Modal asing atau hutang hanya bersifat sebagai pelengkap saja jika struktur aktiva sudah tidak memadai untuk keberlangsungan operasional perusahaan. Perusahaan yang memiliki aktiva tetap yang lebih tinggi dibanding aktiva lancar maka akan mengurangi penggunaan modal asing atau hutang, karena perusahaan menganggap sumber pendanaan internal lebih memiliki risiko yang kecil dan dana tersebut sudah mencukupi kebutuhan dananya.

2. Ukuran perusahaan dalam penelitian ini tidak berpengaruh terhadap struktur modal. Hal ini terjadi karena besar kecilnya suatu perusahaan tidak mempengaruhi pendanaan terhadap struktur modal, karena dalam penggunaan sumber dana yang berasal dari modal sendiri atau hutang, tentu mempunyai biaya modal yang berbeda dengan tingkat resiko yang berbeda pula. Dalam setiap perusahaan tentu lebih memilih untuk menggunakan pendanaan secara internal sesuai dengan teory pecking order.

3. Likuiditas menunjukkan bahwa berpengaruh terhadap struktur modal, hal ini ditunjukkan dengan berdasarkan teory pecking order dimana kondisi likuiditas perusahaan yang tinggi, maka perusahaan akan cenderung memilih menggunakan pendanaan internal untuk pembiayaan operasional perusahaan dibandingkan dengan penggunaan modal asing atau hutang.

4. Profitabilitas dalam penelitian ini tidak berpengaruh terhadap struktur modal, hal ini dikarenakan dengan adanya kemungkinan tingkat profitabilitas perusahaan yang rendah, maka perusahaan akan cenderung menggunakan penggunaan utang yang lebih banyak untuk membiayai kegiatan operasional perusahaan. Dimana perusahaan akan kesulitan saat tidak mampu menutup beban hutang yang dimiliki oleh perusahaan pada masa lampau. Hal ini tidak bisa disesuaikan dengan teori pecking order yang menyatakan bahwa semakin tinggi tingkat profitabilitas perusahaan, maka akan semakin tinggi pula penggunaan dana internal, dan memerlukan hutang yang lebih sedikit.

\section{DAFTAR PUSTAKA}

Apsari, G. A., \& Dana, I. M. (2018). Pengaruh Profitabilitas, Struktur Aktiva, dan Size Terhadap Struktur Modal Pada Perusahaan Barang Konsumsi Di BEI. E-Jurnal Manajemen Unud, Vol. 7, No. 12, 6842-6871.

Ariani, N. K., \& Wiagustini, N. L. (2017). Faktor-faktor yang Mempengaruhi Struktur Modal Perusahaan Property dan Real Estate yang Terdaftar dI BEI. E-Jurnal Manajemen Unud, Vol. 6, No. 6, , 31683195.

Batubara, R. A., Topowijono, \& Zahroh, Z. (2017). Pengaruh Struktur Aktiva, Ukuran Perusahaan, dan Profitabilitas Terhadap Struktur Modal (Studi Pada Perusahaan Makanan dan Minuman yang Terdaftar di Bursa Efek Indonesia Tahun 20122015). Jurnal Administrasi Bisnis (JAB), https://doi.org/administrasibisnis.studentjournal.u b.ac.id .

Brigham, E. F., \& Houston, F. J. (2006). Dasar-Dasar Manajemen Keuangan Edisi 10. Jakarta: Salemba empat.

Dahlena, M. (2017). Pengaruh Likuiditas, Resiko Bisnis, Profitabilitas Terhadap Struktur Modal Pada Perusahaan Textile dan Garment yang Terdafar di Bursa Efek Indonesia. Jurnal Riset Akuntansi \& Bisnis , 1693-7597.

Denziana, A., \& Yunggo, E. D. (2017). Pengaruh Profitabilitas, Struktur Aktiva, Dan Ukuran Perusahaan Terhadap Struktur Modal Perusahaan Pada Perusahaan Real Estate And Property Yang Terdaftar Di Bursa Efek Indonesia Tahun 2015. Jurnal Akuntansi \& Keuangan, 51-57.

Dewiningrat, A. I., \& Mustanda, I. K. (2018). Pengaruh Likuiditas, Profitabilitas, Pertumbuhan Penjualan\& Struktur Aset Terhadap Struktur Modal. E-Jurnal Manajemen Unud, Vol. 7, No. 7 , 3471-3501.

Dewiningrat, A. I., \& Mustanda, I. K. (2018). Pengaruh Likuiditas, Profitabilitas, Pertumbuhan Penjualan, dan Struktur Aset Terhadap Struktur Modal . EJurnal Manajemen Unud, Vol. 7 , 3471-3501.

Firmanullah, N., \& Darsono. (2017). Faktor-faktor yang Mempengaruhi Struktur Modal di Perusahaan Indonesia (Pada Perusahaan Manufaktur yang Terdaftar di BEI Tahun 2011-2014). Diponegoro Journal of Accounting , 1-9.

Horne, J. C., \& John M, W. (2012). Prinsip - Prinsip Manajemen Keuangan, Edisi Kedua Belas, Buku Kedua. Jakarta: Salemba Empat.

Lasut, S. J., Rate, P. V., \& Raintung, M. C. (2018). Pengaruh Ukuran Perusahaan, Profitabilitas, dan Likuiditas Terhadap Struktur Modal Pada Perusahaan Otomotif Yang Terdaftar di Bursa 
Efek Indonesia Periode 2012-2015. EMBA, 6 (1), 11-20.

Maryanti. (2016). Analisis Profitabilitas, Pertumbuhan Perusahaan, Pertumbuhan Penjualan dan Struktur Aktiva Terhadap Struktur Modal Pada Perusahaan Sektor Industri Barang Konsumsi yang Terdaftar di Bursa Efek Indonesia. Riset Akuntansi dan Keuangan Indonesia, 1(2) .

Tangiduk, D., Rate, P. V., \& Tumiwa, J. (2017). Analisis Pengaruh Ukuran Perusahaan, Struktur Aktiva, dan Profitabilitas Terhadap Struktur Modal Pada Perusahaan Manufaktur Sektor Industri Dasar dan Kimia yang Terdaftar di Bursa Efek Indonesia Periode 2011-2015. Jurnal EMBA , 874 - 883. 